\title{
Os africanos livres na Real Fábrica de Ferro São João do Ipanema: Funções, Origens Étnicas e Rotina de Trabalho (1840-1850).
}

\author{
Mariana Alice Pereira Schatzer Ribeiro*
}

Resumo: O presente artigo analisa a experiência dos africanos livres, na Real Fábrica de Ferro São João do Ipanema, em Sorocaba-SP, entre 1840 a 1850. Para tal, abordo, primeiramente, as questões sociais e políticas que originaram este grupo específico. Em seguida, amparada pelas fontes presentes no Arquivo Público do Estado de São Paulo, avalio a trajetória dos trabalhadores no empreendimento fabril como funções, data de chegada, e principalmente as origens étnicas dos mesmos, tendo em vista a demasiada importância que representam na diáspora. Nesse sentido, os africanos tinham a consciência de sua condição jurídica de "livre", mas na prática para o Estado Imperial brasileiro eram apenas mais um grupo de escravos lutando por sua liberdade.

Palavras-chave: africanos livres, Ipanema, escravidão, experiências.

\begin{abstract}
This article analyzes the experience of free Africans in Real Fábrica de Ferro São João do Ipanema, in Sorocaba-SP, between 1840-1850. To do this, first aboard the social and political issues leading to this particular group. Then, supported by the sources present in the Public Archives of the State of São Paulo, evaluate the trajectory of workers in the enterprise functions like manufacturing, date of arrival, and especially the ethnic origins of the same, with a view to representing too much importance in the diaspora. Accordingly, Africans were aware of their legal status "free", but in practice for the Brazilian Imperial State were just another group of slaves fighting for their freedom.
\end{abstract}

Keywords: free African, Ipanema, slavery, experience.

Mestranda em História- UNESP - Universidade Estadual Paulista “Júlio de Mesquita Filho", Faculdade de Ciências e Letras- Campus de Assis. Bolsista FAPESP. E-mail: mariana_schatzer@yahoo.com.br 


\subsection{A legislação sobre o tráfico de escravos.}

Antes de se pensar na categoria dos africanos livres, é preciso compreender como a legislação que os denominou como tal fora criada, além do contexto político acerca das pressões inglesas à coroa portuguesa. Durante todo o século XIX, o governo britânico realizou uma empreitada abolicionista que gerou diversas transformações em seu país, nas suas colônias e também aos países os quais foram impostos as medidas ${ }^{1}$. Entre as exigências estavam: assinatura de tratados, capturas e condenação dos navios negreiros, e a emancipação dos escravizados encontrados a bordo dos mesmos.

Os primórdios da pressão britânica para o fim do tráfico remontam a 1810, quando Portugal assina o Tratado de Aliança e Amizade. Neste combinado, o império luso deveria permanecer com o tráfico apenas nos territórios africanos que lhe fosse de direito. Passado alguns anos, a Convenção Adicional de 28 de julho de 1817 regulamentou o fim do comércio ao Norte da Linha do Equador $^{2}$ e o apresamento dos navios que estivessem na região.

Ademais, os africanos apreendidos nos navios ilegais deveriam ser libertos e utilizados como trabalhadores livres, tutelados pelo Estado ${ }^{3}$. Porém, foi somente com o Alvará português de 26 de janeiro de 1818, que ficou determinado o tempo máximo desta tutela: um período de 14 anos $^{4}$.

Não obstante, em 1822, o Brasil tornou-se independente de Portugal. Logo, o país necessitava de um amparo, de ser reconhecido como um Estado independente politicamente

1 Sobre a relação e o impacto da campanha abolicionista inglesa em suas colônias ver: DRESCHER, Seymour. Abolição: uma história da escravidão e do anti- escravismo. São Paulo: Ed. da UNESP, 2011. WILLIAMS, Eric. Capitalismo e escravidão. Rio de Janeiro: Americana, 1975.

2

Segundo Jaime Rodrigues, a região compreendia a Costa da Mina (atuais Daomé e Nigéria, na África Ocidental). RODRIGUES, Jaime. O infame comércio: propostas e experiências no final do tráfico de africanos para o Brasil (1800-1850). Campinas: Ed. UNICAMP- CECULT, 2000, p.98. Para mais detalhes sobre tratados internacionais, ver o capítulo 03: "A pressão inglesa: honra, interesses e dignidade". Págs.97-125.

3 “Convenção Adicional de 28 de julho de 1817”, Coleção das Leis do Império do Brasil, 1817, Biblioteca Nacional.

4 “Alvará de 26 de janeiro de 1818”, Coleção das Leis do Império do Brasil, 1818, Página 07 Vol. 1, Biblioteca Nacional. 
através de uma nação estrangeira. Obviamente, o governo luso a princípio não quis reconhecer a independência brasileira. Por outro lado, havia um interesse muito grande por parte dos ingleses.

A fim de que a independência do Brasil se concretizasse, o governo inglês fez a mediação das discussões com os portugueses, até que em 1825 eles efetuaram o reconhecimento da autonomia. Em seguida, a Grã-Bretanha realizou o mesmo ato, todavia exigia uma condição nada confortável para a política e sociedade brasileira do período: o fim do tráfico transatlântico de escravos. A exigência era bastante perturbadora, visto que o Brasil desde finais do século XVI já havia se tornado uma sociedade profundamente arraigada no sistema escravista. De acordo, com Stuart Schwartz: "a norma era usar os escravos em regime de produção máxima, baixando os custos e mantendo um esquema de trabalho intensivo". 5

Sendo assim, dificilmente seria possível abolir o tráfico de escravos em um local aonde a escravidão era o alicerce de seu desenvolvimento. Segundo David Brion Davis, a ideologia e a infraestrutura judicial estavam montadas não só para favorecer um sistema de exploração de trabalho, como também para garantir "a preservação da segurança pública e a perpetuação do poder nas mãos de uma predominante casta de brancos". ${ }^{6}$ Portanto, tal situação vantajosa não poderia se acabar, na opinião de políticos, e principalmente, dos proprietários de terra e de escravos.

Após o reconhecimento da independência pela Inglaterra houve a Convenção de 23 de novembro de 1826, nela o governo britânico e o recente Império brasileiro mantiveram os acordos assinados com Portugal, como também criaram o Tratado Anglo-brasileiro. Com isto, o tráfico passou a ser considerado pirataria e deveria ser extinto em três anos. Também foram criadas comissões mistas em Londres, Rio de Janeiro e Serra Leoa para julgar os navios apreendidos ${ }^{7}$.

Por sua vez, em novembro de 1831, durante o caos do período regencial, após a

5 SCHWARTZ, Stuart. Escravos, roceiros e rebeldes. Bauru: EDUSC, 2001, p. 93.

6 DAVIS, David Brion. O problema da escravidão na cultura ocidental. Rio de Janeiro: Civilização Brasileira, 2001, p. 271.

7 “Convenção de 23 de novembro de 1826", Coleção das Leis do Império do Brasil, 1826, Biblioteca Nacional. 
abdicação e saída de Dom Pedro I, e em conjunto com a ascensão de um ministério liberal, foi sancionada por Felisberto Caldeira Brant, o Marquês de Barbacena, a lei que designou a categoria dos "africanos livres". A Lei determinava o seguinte:

A Regência, em nome do Imperador o Senhor Dom Pedro Segundo, faz saber a todos os súditos do Império, que a Assembléia Geral decretou, e ela sancionou a Lei seguinte: Art. $1^{\circ}$. Todos os escravos, que entrarem no território ou portos do Brasil, vindos de fora, ficam livres. ${ }^{8}$.

Ademais, ficara decidido que os africanos presos deveriam imediatamente ser conduzidos de volta à África, custeados pelos traficantes que os aprisionava. Entretanto, devido à ineficácia e lentidão para o cumprimento da medida, várias pessoas permaneceram alojadas na Casa de Correção da Corte $^{9}$ enquanto aguardavam a decisão sobre seus destinos. Poucos africanos de fato foram reexportados para seu continente, pois a grande maioria permaneceu no Brasil tutelados, utilizados em obras e instituições públicas como a Fábrica de Ferro Ipanema. Na prática, o Estado brasileiro buscava uma alternativa entre a extinção do tráfico e o impedimento de um possível choque político com a Inglaterra.

A norma ficou conhecida como: "lei para inglês ver", porque não pôs um fim definitivo ao comércio negreiro e tampouco atendeu as expectativas do governo britânico. O desrespeito à cláusula foi realizado pelas mais importantes autoridades, representadas por políticos, juízes e também por oficiais, funcionários portuários, comerciantes e traficantes de escravos. Fato este que demonstra o interesse das mais variadas camadas da sociedade na lógica escravista.

Com o fim do período regencial (1831-1840), das disputas políticas internas e com a demissão do Gabinete da Maioridade (de tendências abolicionistas) devido à emancipação

8 Lei de 07 de novembro de 1831. Coleção de Leis do Império do Brasil, 1831. Biblioteca Nacional. Optou-se por deixar a ortografia original do documento exposto.

9 A Casa de Correção da Corte, construída na década de 1830 abrigou centenas de africanos que chegaram ilegalmente no país. Além disso, a penitenciária tinha como objetivo transformar aqueles que haviam cometido crimes em pessoas laboriosas, através do trabalho como cumprimento das penas. Para mais informações sobre a participação dos africanos livres e os detentos no estabelecimento ver: ARAÚJO, Carlos Eduardo Moreira de. Cárceres Imperiais: A Casa de Correção no Rio de Janeiro. Seus detentos e o sistema prisional no Império (1830-1861). Tese de Doutorado, Campinas-SP: UNICAMP, 2009. 
de Dom Pedro II, o esforço do governo em reprimir o comércio negreiro tornou-se cada vez mais relaxado. Por outro lado, a pressão britânica fazia-se latente, visto que os ingleses estavam determinados em fazer com que o negócio fosse abolido.

Com a recusa do governo brasileiro em fazer valer os acordos, a Inglaterra estabelece um tratado unilateral, o Slave Trade Suppression Act, o qual resultou em 08 de agosto de 1845 na lei Bill Aberdeen ${ }^{10}$. A legislação determinava que o governo inglês poderia julgar as embarcações e seus comandantes como piratas em tribunais ingleses, não importando o local onde fossem capturadas (África ou Américas). ${ }^{11}$

Deste modo, o tráfico estava sujeito à repressão, independente de qualquer contato prévio entre o Império Britânico e o país responsável pela carga. Entre os anos de 1840 e 1848, a marinha inglesa apreendeu mais de 600 navios, carregando milhares de africanos. Muitos deles foram conduzidos às colônias inglesas do Caribe onde, apesar de receberem um soldo, viveram em condições muito próximas a dos escravos ${ }^{12}$. Após esta lei começou a declinar o número de africanos capturados com o tráfico. Vale lembrar que o período era conturbado e havia muitas preocupações em jogo, muitas autoridades tinham a consciência do dever de acabar com o tráfico. No entanto, temiam as consequências sociais e econômicas da medida.

Somente em 1850 é que foi retomada a discussão acerca da legislação de 1831, através da lei sancionada em 04 de setembro, mais conhecida como "a lei Eusébio de Queiróz”. A norma previa processar traficantes, capitães, tripulação e todos os envolvidos no sistema ilegal. Por sua vez, os escravos presentes nas embarcações apreendidas ou na costa, deveriam ser libertos e continuar sob a guarda do governo brasileiro ${ }^{13}$. Apesar das falhas e lacunas presentes na legislação, foi só a partir dela que o tráfico de escravos

10 O nome é uma referência ao lord Aberdeen, então Ministro das Relações Exteriores da Grã-Bretanha.

11 Sobre as negociações detalhadas entre o Brasil e a Inglaterra ver: LESLIE, Bethell. A abolição do tráfico de escravos no Brasil: a Grã Bretanha, o Brasil e a questão do tráfico de escravos, 1807-1869. Rio de Janeiro: EDUSP/Expressão e Cultura, 1976, págs. 232-254.

12 Mamigonian em sua tese de doutorado aborda ricamente a questão da abolição do tráfico entre os dois países, como também discute as políticas empregadas pela Inglaterra em suas colônias, entre elas a do Caribe. MAMIGONIAN, Beatriz G. To be a liberated African in Brazil: labour and citzenship in the nineteenth century. PhD, History. Waterloo: University of Waterloo, 2002.

13 Lei n. 581 de 04 de setembro de 1850. Coleção das Leis do Império do Brasil. Abolição do Tráfico de Escravos, Tomo XI, parte 1a, 267-261, Biblioteca Nacional. 
diminuiu significativamente chegando ao final no Brasil.

Enquanto eram travados os debates sobre o comércio negreiro entre intelectuais e parlamentares, nenhuma outra medida havia sido tomada a respeito da liberdade efetiva dos africanos tutelados no país. Somente com o decreto de 28 de dezembro de 1853 foi possível definir a liberdade daquelas pessoas. Inicialmente, apenas foram "contemplados" os africanos que tivessem trabalhado durante 14 anos, exclusivamente para particulares ${ }^{14}$.

No entanto, analisando mais detalhadamente a referida iniciativa, pode-se perceber que o governo brasileiro acabou revelando o não cumprimento do Alvará de 1818, o qual determinava o período de 14 anos da tutela, pois todos concluíram o tempo de serviço quando o decreto de 1853 foi emitido. Sendo assim, "a maioria deles trabalhou muito tempo antes receber suas cartas finais de emancipação" ${ }^{15}$.

Já, a liberdade para todos os trabalhadores tutelados ocorreu em 1864. As cartas deveriam ser expedidas pelo Juiz de Órfãos da Corte e pelos Presidentes das Províncias. Após o processo eram destinadas aos chefes de polícia para serem entregues aos emancipados ${ }^{16}$. Todavia, mesmo após esta data ainda foram encontrados africanos livres em alguns estabelecimentos imperiais.

Vale lembrar, que ao longo destes 40 anos, devido a uma preocupação do estado em identificá-los e controlá-los existe uma riqueza documental sobre os mesmos, permitindo aos estudiosos comparar e estudar este grupo social de diversas formas a partir dos anos 2000.

\subsection{A Fábrica de Ferro Ipanema: panorama histórico.}

A Fábrica de Ferro Ipanema foi um estabelecimento muito importante e esteve na ordem da agenda do governo imperial. Deste modo, há diversos documentos produzidos pelos órgãos brasileiros durante todo o século XIX, como por exemplo, os relatórios dos

14 Decreto 1303 de 28 de dezembro de 1853. Coleção das Leis do Império do Brasil, Biblioteca Nacional.

15 MAMIGONIAN, Beatriz G. To be a liberated African in Brazil: labour and citzenship in the nineteenth century. PhD, History. Waterloo: University of Waterloo, 2002, p. 239.

16 Decreto n³310 "Emancipação dos Africanos Livres". 24 de setembro de 1864. Coleção das Leis do Império do Brasil, 160-161, Biblioteca Nacional. 
presidentes da Província de São Paulo e os relatórios do Ministério da Guerra, o qual o empreendimento esteve subordinado até 1877. A Fábrica de Ferro Ipanema, conhecida como uma das primeiras estabelecidas no Brasil tem sua origem em meados de 1765, data da primeira amostra de ferro fundida na região, a qual englobava o morro de Araçoiaba, também conhecido como Ipanema que lhe dera o nome. Durante o século XIX, as indústrias no Brasil se estabeleciam fora das áreas urbanas, usufruindo fontes de energia, fornecimento de matéria-prima e eram bastante artesanais. A partir da administração da capitania de São Paulo realizada por Luís Antônio de Souza, o Morgado de Mateus iniciouse então as primeiras experiências metalúrgicas com o ferro. Este a enviou para o Marquês de Pombal, e afirmou que: "as explorações de minas de ferro se mostravam mais úteis que as de ouro". ${ }^{17}$.

A criação do estabelecimento foi pensada para atender as necessidades estratégicas, militares, de defesa, como também de povoamento, visto que a capitania possuía baixa densidade populacional no momento. Assim, através da Carta Régia de 1810, o estabelecimento passa a se chamar Real Fábrica de Ferro São João do Ipanema. No documento, também existem informações sobre a chegada dos primeiros escravos, bois e outros investimentos do governo português, conforme aponta o documento assinado pelo príncipe regente:

\begin{abstract}
Sendo de suma utilidade criar no Brasil estabelecimentos de minas de ferro, na maior extensão possível, que possam dar ferro e servir de base às preciosas manufaturas do mesmo metal, não só para o consumo do Brasil, mas ainda servir de objeto de exportação, o que será ao comércio destes estados de suma utilidade, e havendo constado na minha real presença, que em Sorocaba, na capitania de São Paulo, há uma mina de ferro muito rica. ${ }^{18}$.
\end{abstract}

Com relação aos africanos, após a aprovação da lei de 1831 houve a determinação

17 DANIELI Neto, op. cit., p.85.

18 VERGUEIRO, Nicolau Pereira de Campos. História da Fábrica de Ipanema e Defesa perante o Senado. Brasília, Senado Federal, 1979, p. 58. 
assinada em 19 de novembro de $1835^{19}$. A lei dizia que todos os tutelados apreendidos fossem depositados na Casa de Correção da Corte-RJ, para que em seguida fossem destinados a seus concessionários particulares ou às instituições públicas. No mesmo ano de 1835, chegou o primeiro grupo proveniente da Corte na Real Fábrica de Ferro. Durante a entrega, o Presidente da Província de São Paulo lembrava as obrigações do diretor perante eles:

Esperando por último este governo, que o sobredito senhor diretor terá da sua parte a maior vigilância não só sobre a conservação destes indivíduos, a fim de que não possam a vir a ser presa de algum ambicioso que os desencaminhe e os reduza a cativeiro, como mesmo sobre o seu bom tratamento e competente ensino. ${ }^{20}$

Sem contar com a extrema vigilância salientada pelo Presidente da Província, a rotina exercida na instituição era muito rígida, porque não existia permissão para os tutelados deixarem os estabelecimentos e escolherem as suas atividades. Além do mais, as condições de controle disciplinar e tempo de trabalho tornavam a jornada muito exaustiva, devido à própria natureza do empreendimento. Como demonstra este documento:

Os trabalhos diários da oficina são de 5 horas da manhã até às 8 horas da noite, bem entendido no verão se terá meia hora para o almoço e uma hora e meia para o jantar, no inverno meia hora para o almoço e uma hora para o jantar ${ }^{21}$.

Pode-se perceber como os trabalhos eram exaustivos, os trabalhadores tinham poucos momentos para fazer suas refeições. Ademais, os tutelados ocuparam diversas funções na fábrica: mestre de fundição, mestre moldador, mestre de refino, mestre fundidor,

19 Coleção de Leis do Império do Brasil - 1835. http://www2.camara.leg.br/legin/fed/decret sn/18241899/decreto-37084-19-novembro-1835-563013-publicacaooriginal-87123-pe.html. Acesso em 08 de abril de 2013, às 16h: $35 \mathrm{~m}$.

20 AESP. Fábrica de Ferro Ipanema. 28 de junho de 1835. Ofício do Presidente Francisco Antônio de Souza Queirós ao diretor da fábrica

21 AESP. Fábrica de Ferro Ipanema. 25 de maio de 1835. Contrato de trabalho com mestre ferreiro. Ordem CO 5214. 
entre outras ${ }^{22}$. Vale lembrar que todas as atividades relativas ao ferro e a metalurgia eram desempenhadas somente pelos homens adultos. As mulheres, as crianças e os idosos eram os responsáveis pela criação de animais e a agricultura ${ }^{23}$.

Alguns estudos apontam que os africanos já exerciam o ofício da metalurgia em seu continente, principalmente na região centro-ocidental. Aliás, o impacto proveniente de tal produção econômica fez com que estes profissionais detivessem uma posição social diferenciada na sociedade africana. Segundo a crença do povo, lidar com a metalurgia era também lidar com a transformação da natureza, do mundo vegetal e animal, através de regras e rituais associados a esferas não humanas. Em muitos locais, os ferreiros eram considerados reguladores da fertilidade por estarem associados aos espíritos da terra, desempenhando importantes funções de chefe ${ }^{24}$.

Embora haja toda uma mítica e conhecimento anterior associado aos africanos, enfatizamos que não fora por esses motivos que os mesmos vieram trabalhar em Ipanema, a experiência previa era apenas mais um motivo para exploração. $\mathrm{O}$ que prevaleceu foi a lógica do sistema escravista brasileiro desempenhado na fábrica, o qual utilizou a mão-deobra passível de controle a fim de alcançar o seu desenvolvimento. Como aponta Carlos Eduardo M. Araújo:

22 Quanto à especificidade de algumas funções, os ferreiros fundidores, extraíam o minério de ferro da terra e faziam a sua fundição; já os ferreiros forjadores transformavam o ferro já fundido em objeto como armas, caçarolas, ferramentas, etc. Tais informações não estão presentes na documentação referente à Fábrica de Ferro, mas foram extraídas do livro Homens de ferro. Infelizmente não há certeza se a técnica utilizada pelos escravos e africanos livres de Ipanema, era semelhante à empreendida na África Central durante o século XIX. Sobre os ofícios com o ferro ver: Silva, Juliana Ribeiro da. Homens de ferro: Os ferreiros na África Central no século XIX. São Paulo: Alameda, 2011, p. 137.

23 A agricultura foi muito praticada na fábrica, as roças geralmente eram cultivadas pelas mulheres, crianças e idosos. Nelas havia plantações de milho e feijão, destinadas ao abastecimento interno, principalmente para a alimentação dos próprios africanos e escravos.

24 SILVA, Juliana Ribeiro da. Homens de ferro: Os ferreiros na África Central no século XIX. São Paulo: Alameda, 2011, p. 13. A autora aborda os vários significados que os ferreiros tinham para as sociedades centro-africanas, entre eles o social, o econômico, o político e também o religioso. O trabalho traz grandes contribuições, visto que a temática foi pouco estudada no Brasil até o momento. Ademais, Juliana salienta o interesse da atividade pelos portugueses no continente africano, o que pode ser demonstrado pela criação em 1765, da Fábrica de Ferro de Nova Oeiras, em Angola, a qual teve como mão-de-obra grupos diversos de trabalhadores. Pode ter sido proposital, acaso, ou coincidência da história, mas tanto a Fábrica de Ipanema, quanto a de Nova Oeiras foram criadas no mesmo ano, com um sistema de trabalho e mão-de-obra parecidas. Por sua vez, acerca do poder político há também os mitos sobre os reis ferreiros, associados à fundação dos estados africanos, bastante conhecido através de Joseph Miller. Sobre isto ver também p. 61-69. 
A distribuição dos africanos livres pelas obras públicas e a particulares evitava um gasto excessivo com o sustento dessas pessoas em depósitos e ainda possibilitaria ao Estado arrecadar com a exploração de sua mão-de-obra ${ }^{25}$.

O número de africanos livres presentes na fábrica de ferro nunca fora uma constante, a quantidade se modificava ao longo dos anos, principalmente devido às fugas, transferências para outros estabelecimentos e mortes. Por exemplo, em 1841 havia 104 africanos, em 1846 a instituição contava com 240 (compostos por 196 homens, 23 mulheres e 21 crianças). Já, em 1854 existiam 131 africanos livres, dentre os quais 20 encontravamse doentes e inválidos ${ }^{26}$.

Além disso, os africanos livres e os escravos residiam em taipas piladas e eram obrigados a realizar inúmeras atividades no plantel; como participar das missas, seguir os preceitos da fé cristã, sem esquecer da vigilância e opressão diária dos feitores. Nesse sentido, havia um regulamento sobre as atividades dos mesmos:

Art.38: A escravatura e os gados ficarão sujeitos e a cargo de um ou mais feitores em tudo subordinados ao vice-diretor, a quem recorrerá para providências sobre o sustento, vestuário, e curativo deles. ${ }^{27}$

Apesar da vigilância realizada pelos feitores havia um medo e preocupação por

25ARAÚJO, Carlos E.M. Arquitetando a liberdade: os africanos livres e as obras públicas no Rio de Janeiro imperial. In, História Unisinos, 14(3): 329-333 Setembro/Dezembro 2010, p.06.

26 Nos capítulos seguintes será discutida mais detalhadamente a questão populacional dos africanos em Ipanema. Ademais, com o decorrer dos anos os números caem drasticamente, como por exemplo, em 1863; um ano antes da promulgação da lei da emancipação definitiva, havia na instituição apenas 15 africanos livres vivendo em profunda miséria.

27 AESP, Fábrica de Ferro Ipanema, 26 de maio de 1834. Regulamento provisório para a administração da fábrica. Ordem CO 5512, caixa no 04. 
parte das autoridades com relação aos tutelados, seja por decorrência das fugas, ou devido à possibilidade de uma corrupção dos costumes, de influenciarem os cativos em conflitos e revoltas. Em ofício acerca da mão-de-obra, o diretor do empreendimento, o Major João Bloem $^{28}$ dissertava sobre os mesmos:

[...] Eles são relaxados, mostram sempre uma cara feia, e parece que são seduzidos por algum mal- intencionado, pois há entre eles alguns de 05 a 08 fugidas, e não servem correções. ${ }^{29}$.

Por conta de sua condição, veremos posteriormente que a principal diferença no tratamento perante os tutelados foi com relação à vigilância, opressão e coerção dos administradores.

A utilização da mão-de-obra dos africanos livres como trabalhadores no Brasil oitocentista foi distribuída em $82 \%{ }^{30}$ entre os locatários privados, (normalmente os senhores de escravos, considerados íntegros e de confiança do governo) ${ }^{31}$. Já, entre as instituições espalhadas pelo império, foram disseminados aproximadamente cerca dos $18 \%{ }^{32}$ dos recapturados.

Nesse sentido, não apenas a Fábrica de Ferro Ipanema contou com os serviços obrigatórios prestados por aquelas centenas de homens e mulheres, categorizados na lei de 07 de novembro de 1831, como outros estabelecimentos na Província de São Paulo e Rio de Janeiro. Tais estabelecimentos em São Paulo eram: a Colônia Militar de Itapura, o

28 O Major João Bloem era natural da Renânia (oeste da Alemanha) e ocupou a direção entre os anos de 1835 a 1842 . Em seu lugar assumiu o tenente, Antonio Manoel de Mello, que permaneceu na administração de 1843 a 1845.

29 . AESP, Fábrica de Ferro Ipanema, 28 de fevereiro de1842. Relatório do diretor ao presidente da província de São Paulo. Ordem n ${ }^{\circ} 5215$.

30 MAMIGONIAN, Beatriz Gallotti. To be a liberated African in Brazil: labour and citizenship in the nineteenth century. Tese de Doutorado em História. University of Waterloo, 2002, p. 66.

31 A medida foi estabelecida através da Instrução de 29 de outubro de 1834. In: Coleção das Leis do Império do Brasil, 1834, Biblioteca Nacional. Após disseminar os africanos pelas instituições, o Chefe de Polícia enviava os restantes aos particulares. $\mathrm{O}$ arrematante se comprometia em devolver o africano para o governo assim que fosse decidido sobre a sua sorte.

32 MAMIGONIAN, Beatriz Gallotti. To be a liberated African in Brazil: labour and citizenship in the nineteenth century. Tese de Doutorado em História. University of Waterloo, 2002, p. 66. 
Hospício dos Alienados, o Jardim Público. Esses, entre outros, contaram com a participação dos tutelados. No Rio de Janeiro os mesmos foram encontrados, entre outros, na: Casa de Correção, Santa Casa de Misericórdia, Fábrica de Pólvora da Estrela.

\subsection{Nomes, Funções, Naturalidades, Sexo e Rotina de Trabalho}

Em 1835 foram deliberadas as instruções do Ministério da Justiça ${ }^{33}$ para a chegada dos africanos livres em Ipanema ${ }^{34}$. Segundo elas, o diretor com a chegada dos tutelados deveria lavrar um ato contendo informações referentes aos nomes, sinais corporais de identificação e naturalidades ${ }^{35}$. O responsável pelo empreendimento naquele momento era o então, Major João Bloem, conhecido por sua gestão rigorosa, além das constantes queixas sobre a falta de mão-de-obra na fábrica.

No ano de 1837, trabalhavam no empreendimento 48 africanos livres (30 homens e 18 mulheres); 121 escravos (68 homens, 29 crioulos e 24 mulheres). Além disso, havia 12 escravos e um africano evadidos, contabilizando o total de 169 pessoas ${ }^{36}$. Durante a trajetória da instituição, exceto em algumas fases, a maioria dos operários era composta por cativos. A quantidade de africanos sempre foi superior, como analisaremos mais adiante.

Uma das exigências realizadas por Bloem ao governo imperial para assumir a direção estava baseada no aumento do contingente dos trabalhadores. De acordo com o major, o número de operários livres (nacionais, estrangeiros) ${ }^{37}$, africanos e escravos da

33 Instrução n. 143 da Justiça, 06 de junho de 1835. In: Coleção das Leis do Império. Dá providências sobre os africanos livres enviados para a Fábrica de Ferro.

34 Segundo Mário Danieli Neto, os primeiros africanos livres que chegaram à Ipanema eram em número de 48. Todavia, não encontramos informações precisas sobre isto nas fontes compiladas.

DANIELI Neto, Mario. Escravidão e Indústria: Um estudo sobre a Fábrica de Ferro São João do IpanemaSorocaba (SP)-1765-1895.Doutorado em História, Universidade Estadual de Campinas: Instituto de Economia, 2006, p. 150.

35 Apesar da deliberação referente à transcrição dos sinais corporais de identificação, a mesma foi encontrada em poucos documentos.

36 AESP, Fábrica de Ferro Ipanema, 01 de maio de 1837. Mapa dos empregados, escravos e africanos que existem na Fábrica de Ferro de São João do Ipanema. Ordem n 5214 (1835-1839).

37 Como o citado no Capítulo 01, foi durante a administração do Major Bloem que ocorreram os conflitos com os operários prussianos, tendo como consequência a baixa na quantidade de trabalhadores. Entretanto, sobre os operários nacionais livres não encontramos muitas informações, para Jorge Prata de Souza, o número de livres nunca ultrapassou os $25 \%$ do total dos empregados, incluindo-se os nacionais 
nação não davam conta de atender à produção. Assim, algum ano depois, percebendo a lentidão governamental, a fim de fazer valer a reinvindicação, o mesmo queixou-se na correspondência destinada ao Ministério da Guerra:

Se me fornecia 180 a 200 tantos africanos ou escravos de 15 a 30 anos de idade e debaixo destas condições me animei em aceitar o emprego de diretor, vejo eu que estava iludido [...]. Suplico novamente a V. $\mathrm{Ex}^{\mathrm{a}}$. a remessa dos 180 africanos de 15 a 30 anos de idade, homens não mulheres. ${ }^{38}$

A preferência do diretor pelos africanos homens era porque eles exerciam as atividades mais especializadas, como os serviços de alto forno, refinaria e ferro. Como já dito anteriormente, cabiam às mulheres as tarefas relacionadas à agricultura de subsistência, corte, retirada e empilhamento do carvão, muitas vezes auxiliadas por menores e idosos.

Embora existam algumas listagens detalhadas acerca dos tutelados, infelizmente a documentação encontra-se esparsa. Ou seja, não localizamos fontes com uma rígida sequência cronológica. Desta forma, encontramos mapas relativos aos anos de: 1835,1837, 1842, 1846, 1848 e 1849. Ademais, segundo Jorge Luiz Prata de Souza, no tempo de 1839 a companhia possuía 229 indivíduos ${ }^{39}$. Desse total, os africanos somavam 145. Por sua vez, Jaime Rodrigues aponta que no ano de 1841 havia 312 trabalhadores, sendo 104 africanos (e 5 crias $)^{40}$. No entanto, não achamos os referidos documentos para transcrevê-los. Provavelmente, eles deveriam estar em tratamento técnico pelo Arquivo do Estado no momento da consulta.

O governo imperial atendeu uma parte da exigência do Major João Bloem, o número de tutelados enviados à Ipanema aumentou, mas o diretor encerrou a sua

em funções burocráticas. SOUZA, Jorge Prata de. Africano livre ficando livre: Trabalho, Cotidiano e Luta. Tese de Doutorado em História Social. São Paulo: Universidade de São Paulo, 1999, p. 87.

38 NA: IG 5-18. Fábrica de Ferro Ipanema. 1835-1840. Carta do Major do Corpo de Engenharia Major João Bloem ao Ministério da Guerra, em 18 de janeiro de 1839.

39 SOUZA, Jorge Prata de. Africano livre ficando livre: Trabalho, Cotidiano e Luta. Tese de Doutorado em História Social. Universidade de São Paulo, São Paulo, 1999, p. 88.

40 RODRIGUES, Jaime. Ferro, Trabalho e Conflito: os africanos livres na Fábrica de Ipanema. In: Revista de História Social: Campinas - SP, n4/5, 1997-1998, p. 35. O autor também relata a presença de 45 livres (incluindo a direção), 09 guardas municipais, 88 escravos, 33 crioulos e 42 presos. 
administração ainda lamentando a falta de operários. Aliás, a queixa permaneceu ao longo da trajetória da fábrica, estando presente nas correspondências e relatórios produzidos pelos gerenciadores subsequentes.

Em 1843, o então dirigente do empreendimento, Antonio Manoel de Mello ${ }^{41}$ efetua novo pedido ao presidente da Província, a fim de que fossem admitidos mais africanos:

[...] Cumpri-me expor que acho necessários ao menos cem deles, que tenham a robustez conveniente, mas que qualquer número destes acima de quarenta, já irá dar notável aumento ao produto do ferro, por cortar grande parte das dificuldades, com que até agora tenho levado. ${ }^{42}$.

A jornada de produção na fábrica demandava a presença de muitos indivíduos, esta condição se agravou devido à saída dos operários livres estrangeiros na gestão Bloem. Outros acontecimentos como as doenças, mortes, além das fugas recorrentes dos africanos e escravos no estabelecimento agravavam o ritmo de trabalho no plantel. Por isso, Melo declarava a necessidade de, ao menos, cem deles, preferencialmente fortes, robustos, pois a natureza do trabalho exigia pessoal com condição física adequada, conforme demonstra a tabela abaixo:

$41 \mathrm{O}$ tenente Antonio Manoel de Mello permaneceu à frente do empreendimento de 1843 a 1845, ele entrou no lugar do Major Bloem, porque o mesmo ao se envolver na Revolução Paulista de 1842, foi destituído do cargo pelo presidente da Província. A Revolta originou-se em decorrência das disputas políticas entre liberais e conservadores. O partido liberal havia fraudado as eleições para a Assembleia dos Deputados, mas os conservadores exigiram a anulação dos votos e conseguiram retomar ao poder. Todavia, os liberais não aceitaram tal fato e começaram a Revolução pela cidade de Sorocaba, liderados por Antônio Feijó, Brigadeiro Tobias Aguiar e Bloem. O conflito seguiu até a província de Minas Gerais, pois os revoltosos desejavam conquistar novamente o poder através da luta armada, porém logo foram derrotados pelo Barão de Caxias. Alguns elementos conseguiram escapar e refugiaram-se no Rio Grande do Sul, acolhidos pelos Revolucionários Farroupilhas. Por fim, com a retomada dos liberais no jogo político, em 1844 , todos os seus pares envolvidos receberam a anistia.

42 AESP, Fábrica de Ferro São João do Ipanema, 07 de novembro de 1843. Correspondência do diretor Antonio Manoel de Mello ao presidente da província de São Paulo. Ordem n ${ }^{\circ}$ CO 5215 (1840-1848). 
Tabela 1 : Lista das atividades realizadas pelos escravos da Nação e africanos livres existentes na Fábrica de Ferro São João do Ipanema (1835-1845) ${ }^{43}$.

\begin{tabular}{|c|c|c|}
\hline $\begin{array}{l}\text { Atividades } \\
\text { 1- Alto Forno }\end{array}$ & 4- Oficina de Carpintaria & Peneirar, torrar o fubá \\
\hline Mestre do cadinho e forno & Contramestres & Corte de Madeiras \\
\hline Ajudante de cadinho e forno & Oficiais & Juntar e empilhar carvão \\
\hline Carregadores & Aprendizes & Tiradores de carvão \\
\hline Ajudante de carregadores & 5- Diversos & Instaladores linha para carvoaria \\
\hline Ajudantes de misturas & Serra d'água & Queimadores de carvão \\
\hline Moldadores & Moinho & Mineiros \\
\hline Aprendizes de moldadores & Pilões de Mineral & Costureiras \\
\hline 2- Refino: & Arrieiros & Servente na casa do diretor \\
\hline Refinadores & Carreiros & Maquinista \\
\hline Mestre do malho & Pedreiros & \\
\hline Aprendiz de refino & Serventes de Pedreiros & \\
\hline 3- Ferraria & Falquejadores & \\
\hline Contramestre & Criação porcos/cavalos/bois & \\
\hline Oficiais & Enfermeiros & \\
\hline Aprendizes & Cozinha & \\
\hline
\end{tabular}

Apesar da lista compreender dados até o ano de 1845, as referidas funções foram realizadas durante todo o funcionamento da instituição. A análise da tabela demonstra como a maioria dos postos compunha-se de afazeres exaustivos, principalmente os de refino, ferraria e alto forno. Para chegar à qualidade ideal do ferro, a temperatura nos fornos muitas vezes ultrapassavam os $1000^{\circ} \mathrm{C}$, sendo extremamente perigoso para aqueles que trabalhavam nas proximidades deles.

Todavia, os cargos ocupados no item $\mathrm{n}^{\circ} 05$. (exceto os pedreiros e queimadores de carvões) apresentavam menor grau de periculosidade, exercidos também por mulheres e crianças. Logo, é possível perceber o quanto a fábrica dependia dos africanos e escravos. Seus serviços variavam desde a cozinha, costura aos cargos mais técnicos e especializados.

Ainda acerca da falta de trabalhadores localizamos o relatório produzido na Repartição dos Negócios da Guerra, em 1843, apresentado à Assembleia Geral Legislativa, aonde o Ministro Salvador José Maciel faz uma abordagem realista sobre Ipanema:

[...] Consta das queixas, cem vezes já d'antes repetidas, da falta de braços, e das promessas cem vezes repetidas

43 SOUZA, Jorge Prata de. Africano livre ficando livre: Trabalho, Cotidiano e Luta. Tese de Doutorado em História Social. São Paulo: Universidade de São Paulo, 1999, p. 89. 
de centenas de contos de réis de rendimento anual, no caso de por parte do Governo satisfazer-se a essa condição de braços. E como esses braços nunca hão de ficar à disposição do Diretor; porque os livres não se hão de ir entregar a trabalhos duros e penosos por salários minguados, e os cativos hão de ser sempre aleijados, doentes, e sobretudo fugitivos, como tem sido até agora todos quantos para ali se tem mandado, seguese que nunca as promessas de rendimento se hão de realizar, e que a falta delas não se poderá imputar ao Diretor, que liga à elas uma condição justa e razoável ${ }^{44}$.

Se os livres dificilmente aceitariam executar os trabalhos penosos, situação complexa era a dos cativos e africanos livres. Houve momentos que o governo chegou a enviar alguns deles já debilitados, porém a maioria ficou doente, aleijada após a rotina de trabalho exaustiva. O ministro, seguindo a intenção governamental preocupava-se com a produção, custos e lucros oriundos da fábrica; concordava com a postura do diretor na exigência por mais braços; porém jamais com as condições de vida, de trabalho daquelas pessoas.

Inclusive é de 1843 a relação dos trabalhadores existentes em Ipanema, contabilizando um total de 90 africanos. Na fonte há também referências dos escravos, mas optamos por transcrever apenas às relativas aos tutelados. $\mathrm{O}$ número de cativos nesta fase era de 120 (34 mulheres e 86 homens), fora as 20 crianças abaixo dos dez anos. A relação contém nomes, idades e observações, o último item preenchido com a palavra "pronto" significava apto ao trabalho ${ }^{45}$.

44 Relatório da Repartição dos Negócios da Guerra apresentado à Assembleia Geral Legislativa, 1843. http://memoria.bn.br//720950/per720950 1843 00017.pdf Acesso em 15 de maio de 2013.

45 Nas listagens optamos por seguir a grafia original dos nomes escritos nas fontes. As demais informações foram transcritas de acordo com a norma culta atual. 
Sankofa. Revista de História da África e de Estudos da Diáspora Africana Ano VI, NºXII,

Tabela 2: Relação dos africanos e escravos existentes na Fábrica de Ferro São João do Ipanema em 1843. ${ }^{46}$.

\begin{tabular}{|c|c|c|c|}
\hline \multicolumn{4}{|l|}{ Africanos } \\
\hline Número & Nome & Idade & Observações \\
\hline 01 & Balbino & 30 anos & Pronto \\
\hline 02 & Daniel & 24 anos & Idem \\
\hline 03 & Vicente & 26 anos & Idem \\
\hline 04 & Rogério & 26 anos & Idem \\
\hline 05 & Martinho & 26 anos & Idem \\
\hline 06 & \begin{tabular}{|l|} 
Silvério \\
\end{tabular} & 20 anos & Idem \\
\hline 07 & Juvêncio & 34 anos & Idem \\
\hline 08 & Romão & 27 anos & Idem \\
\hline 09 & Julião & 22 anos & Idem \\
\hline 10 & Francisco & 30 anos & Idem \\
\hline 11 & Estevão & 31 anos & Idem \\
\hline 12 & Felipe & 26 anos & Idem \\
\hline 13 & Anastácio & 40 anos & $\begin{array}{l}\text { Asmático e quase } \\
\text { cego. }\end{array}$ \\
\hline 14 & Alípio & 23 anos & Pronto \\
\hline 15 & Braz & 22 anos & Idem \\
\hline 16 & Thadeo & 36 anos & Idem \\
\hline 17 & Damazio & 26 anos & Idem \\
\hline 18 & Athanazio & 27 anos & Idem \\
\hline 19 & Antão & 40 anos & Idem \\
\hline 20 & André & 18 anos & Idem \\
\hline 21 & Marcolino & 24 anos & Idem \\
\hline 22 & Lúcio & 26 anos & Idem \\
\hline 23 & Augusto & 19 anos & Idem \\
\hline 24 & Ilegível & 17 & Idem \\
\hline 25 & Ilegível & 19 anos & Idem \\
\hline 26 & Laurentino & 18 anos & Idem \\
\hline 27 & Benedito & 19 anos & Idem \\
\hline 28 & Caio & 21 anos & Idem \\
\hline 29 & Luciano & 26 anos & Idem \\
\hline 30 & Bráz & 36 anos & Idem \\
\hline 31 & Gabriel & 22 anos & Idem \\
\hline 32 & Bazílio & 23 anos & Idem \\
\hline 33 & Inoccencio & 24 anos & Idem \\
\hline 34 & Crispiniano & 22 anos & Idem \\
\hline
\end{tabular}

46 AESP, Fábrica de Ferro Ipanema, 25 de outubro de 1843. Relação dos africanos e escravos existentes, elaborada pelo escrivão Antonio Martins da Costa Passos. Ordem n ${ }^{\circ} 5215$ (1840-1848). 
Sankofa. Revista de História da África e de Estudos da Diáspora Africana Ano VI, NºXII,

Dezembro/2013

\begin{tabular}{|c|c|c|c|}
\hline 35 & Bernardino & 29 anos & Idem \\
\hline 36 & Diogo & 33 anos & Pronto \\
\hline 37 & Raymundo & 18 anos & Idem \\
\hline 38 & Bertholdo & 20 anos & Idem \\
\hline 39 & Olegario & 01 ano & Idem \\
\hline 40 & Belmiro & 18 anos & Idem \\
\hline 41 & Rozendo & 22 anos & Idem \\
\hline 42 & Cyrilo & 18 anos & Idem \\
\hline 43 & Cassiano & 23 anos & Idem \\
\hline 44 & Braulio & 28 anos & Idem \\
\hline 45 & Silvestre & 34 anos & Idem \\
\hline 46 & Antonio & 33 anos & Idem \\
\hline 47 & Paulo & 29 anos & Idem \\
\hline 48 & Deziderio & 18 anos & Idem \\
\hline 49 & Guilherme & 32 anos & Idem \\
\hline 50 & Margarida & 30 anos & Idem \\
\hline 51 & Silvania & 16 anos & Idem \\
\hline 52 & Catharina & 24 anos & Idem \\
\hline 53 & Joaquina & 31 anos & Idem \\
\hline 54 & - & - & \\
\hline 55 & Apolianaria & 33 anos & Idem \\
\hline 56 & Theodora & 27 anos & Idem \\
\hline 57 & Felizberta & 36 anos & Idem \\
\hline 58 & Domingas & 15 anos & Idem \\
\hline 59 & Honorata & 30 anos & Idem \\
\hline 60 & Maria & 30 anos & Idem \\
\hline 61 & Luciana & 28 anos & Idem \\
\hline 62 & Ignacia & 37 anos & Idem \\
\hline 63 & Engracia & 27 anos & Idem \\
\hline 64 & Maria Joze & 27 anos & Idem \\
\hline 65 & Evaristo & 25 anos & Idem \\
\hline 66 & Ilegível & 30 anos & Idem \\
\hline 67 & Fulgêncio & 26 anos & Idem \\
\hline 68 & Horácio & 28 anos & Idem \\
\hline 69 & Marcolino & 26 anos & Idem \\
\hline 70 & Pedro & 18 anos & Idem \\
\hline 71 & Leao & 25 anos & Idem \\
\hline 72 & Hemergencio & 28 anos & Idem \\
\hline 73 & Eustaquio & 32 anos & Idem \\
\hline 74 & Lucio & 22 anos & Idem \\
\hline 75 & Florencio & 26 anos & Idem \\
\hline 76 & Herculano & 28 anos & Idem \\
\hline 77 & Lucas & 28 anos & Idem \\
\hline 78 & Honório & 30 anos & Idem \\
\hline
\end{tabular}


Sankofa. Revista de História da África e de Estudos da Diáspora Africana Ano VI, NºXII,

\begin{tabular}{|l|l|l|l|}
\hline $\mathbf{7 9}$ & Gregório & 30 anos & Pronto \\
\hline $\mathbf{8 0}$ & Caetano & 32 anos & Idem \\
\hline $\mathbf{8 1}$ & José & 34 anos & Idem \\
\hline $\mathbf{8 2}$ & Ignacio & 03 anos & Menor \\
\hline $\mathbf{8 3}$ & Joze & 02 anos & Idem \\
\hline $\mathbf{8 4}$ & Laureano & 02 anos & Idem \\
\hline $\mathbf{8 5}$ & Maria do Rozario & 01 anos & Idem \\
\hline $\mathbf{8 6}$ & Archanja & 01 anos & Idem \\
\hline $\mathbf{8 7}$ & Angelica & 03 meses & Idem \\
\hline $\mathbf{8 8}$ & Antonio & 02 anos & Idem \\
\hline $\mathbf{8 9}$ & Camillo & 02 anos & Idem \\
\hline $\mathbf{9 0}$ & Caetano & 30 anos & Pronto \\
\hline $\mathbf{9 1}$ & Manoel Sebastião & $\begin{array}{l}\text { Recém- } \\
\text { nascido }\end{array}$ & Menor \\
\hline & Francisco & - & $\begin{array}{l}\text { Idem, fugido em } \\
1841 .\end{array}$ \\
\hline & Boaventura & - & $\begin{array}{l}\text { Fugiu em tempo } \\
\text { do diretor Major } \\
\text { João Bloem. }\end{array}$ \\
\hline & & & Idem \\
\hline & Telésforo & - & Idem \\
\hline & Juvenal & - & \\
\hline
\end{tabular}

O estudo da lista revela um total de 14 mulheres, sendo a mais nova, Domingas de 15 anos e a mais velha Ignacia de 37. Já, as crianças eram compostas por 03 meninas, (duas com 01 ano, e outra de 03 meses). Nesta lista também existiam 67 homens, o mais novo, de nome ilegível com 17 anos; e os mais velhos Antão e Anastácio, ambos com 40 anos, (este último asmático e quase cego, mas não sabemos se chegou assim ou adoeceu no empreendimento). Ainda havia 06 meninos (o menor, Manoel Sebastião recém- nascido e Ignacio de 03 anos). Na tabela, além de ser citados os 04 homens evadidos, (Francisco, Boaventura, Telésforo, e Juvenal) não há menção de africanos idosos.

Com relação ao gênero é possível comparar o número de homens e mulheres, africanos livres ou escravos da nação, referentes ao período de 1839 a 1858. Assim, de acordo com a fase 1839 a 1842 os escravos (as) constituíam a maioria dos trabalhadores. Os anos de 1855 a 1858 dizem respeito ao momento de intercâmbios com Itapura e as emancipações, ocasionando a brusca diminuição dos trabalhadores. Veja-se: 
Tabela 3: Relação entre os sexos e os totais de escravos da Nação e africanos livres existentes no estabelecimento da Fábrica de Ferro de São João de Ipanema 1839-1858 ${ }^{47}$.

\begin{tabular}{|l|l|l|l|l|l|l|}
\hline Categoria & $\begin{array}{l}\mathbf{1 8 3} \\
\mathbf{9}\end{array}$ & $\begin{array}{l}\mathbf{1 8 4} \\
\mathbf{2}\end{array}$ & $\begin{array}{l}\mathbf{1 8 4} \\
\mathbf{6}\end{array}$ & $\begin{array}{l}\mathbf{1 8 5} \\
\mathbf{5}\end{array}$ & $\begin{array}{l}\mathbf{1 8 5} \\
\mathbf{7}\end{array}$ & $\begin{array}{l}\mathbf{1 8 5} \\
\mathbf{8}\end{array}$ \\
\hline $\begin{array}{l}\text { Escravos } \\
\text { masculinos }\end{array}$ & 61 & 117 & 57 & 27 & 52 & 58 \\
\hline Escravos femininos & 25 & 58 & 52 & 41 & 60 & 60 \\
\hline Escravos menores & 35 & 63 & 32 & 37 & 45 & 44 \\
\hline Total de escravos & $\mathbf{1 2 1}$ & $\mathbf{2 3 8}$ & $\mathbf{1 4 1}$ & $\mathbf{1 0 5}$ & $\mathbf{1 5 7}$ & $\mathbf{1 6 2}$ \\
\hline $\begin{array}{l}\text { Africanos } \\
\text { Masculinos }\end{array}$ & 25 & 46 & 146 & 85 & 91 & 78 \\
\hline $\begin{array}{l}\text { Africanos } \\
\text { femininos }\end{array}$ & 17 & 31 & 15 & 15 & 29 & 16 \\
\hline Africanos menores & 05 & 16 & 09 & 06 & 07 & 05 \\
\hline Total de africanos & $\mathbf{4 7}$ & $\mathbf{9 3}$ & $\mathbf{1 7 0}$ & $\mathbf{1 0 1}$ & $\mathbf{1 2 7}$ & $\mathbf{9 9}$ \\
\hline
\end{tabular}

Através da análise dos dados percebemos que o total de africanos homens foi superior ao de escravos em 1846, 1855, 1857 e 1858. Interessante é o fato de, após as transferências para a Colônia no Mato Grosso, os índices de tutelados permanecerem elevados se comparado aos cativos. Provavelmente isto ocorreu, pois os escravos pertencentes à fábrica deveriam estar idosos e não mais aptos para o trabalho, ainda mais se levarmos em consideração a possibilidade de muitos deles já trabalharem há muitos anos no local. Não obstante, as taxas de mulheres africanas e menores estiveram abaixo das escravas se observamos todo o período da lista. É notória a ideia acerca do número total de escravas serem menores na comparação com os homens nos plantéis. Porém, podemos dizer que, em relação as africanas, a quantidade era ainda mais baixa; não apenas no concernente aos homens, mas, sobretudo, com relação às cativas. Possivelmente, tais percentuais ocorreram, porque as tuteladas permaneceram majoritariamente alocadas aos concessionários particulares.

A tabela 3 foi transcrita na tese de doutorado de Jorge Luiz Prata de Souza, tendo

47 SOUZA, Jorge Prata de. Africano livre ficando livre: Trabalho, Cotidiano e Luta. Tese de Doutorado em História Social. São Paulo: Universidade de São Paulo, 1999, p. 93. 
como referência o Relatório do Ministério da Guerra, presente no Arquivo Nacional- RJ. Todavia, não o encontramos nos relatórios disponíveis no site da Biblioteca Nacional. No entanto, encontramos um resumo estatístico no Arquivo do Estado de São Paulo, elaborado pelo então diretor, o Barão de Itapicuru- Mirim, datado de 08 de dezembro de 1846. Nele, os números são divergentes daqueles encontrados na classificação do Arquivo Nacional.

Não obstante, para 1848, o mapa dos africanos e escravos contabilizava outros números. Nele, há o relato da presença de 115 africanos adultos, e 06 meninos menores de 07 anos. Já, as mulheres africanas totalizavam 16, sendo 08 meninas menores de 07 anos. Sobre os escravos, a taxa aponta 55 homens e 12 menores; além de 53 escravas mulheres e 20 menores $^{48}$. Além disso, há outro ofício do mesmo dia, aonde o diretor relata a rotina de trabalho:

[...] No tocante aos mestres e operários livres não passam de sete, devo mencionar que muitos dos escravos e africanos vão se aperfeiçoando nos ofícios de moldador, ferreiro, carpinteiro e que alguns outros têm adquirido bastante prática do serviço dos fornos altos [...]. O produto do trabalho dos escravos no cultivo das terras, contou de mil trezentos e oitenta e oito alqueires de milho, trinta e três e meio alqueires de feijão e vinte e meio alqueires de arroz. ${ }^{49}$.

O ofício demonstra a escassa quantidade de operários livres, os quais praticamente desaparecem dos documentos após a entrada dos tutelados. Bem como a colheita dos cativos (e africanos) nas roças de subsistência, pois os alimentos eram consumidos dentro do plantel, inclusive na manutenção dos animais.

Embora, nosso foco seja a identificação total do número dos africanos livres da fábrica, não pudemos aqui desmembrá-los dos escravos, porque se assim o fizéssemos analisaríamos apenas uma parte dos documentos. E poderíamos chegar a conclusões

48 AESP, Fábrica de Ferro Ipanema, 15 de novembro de 1848. . Ofício do diretor ao presidente da província de São Paulo. Ordem n ${ }^{\circ}$ CO 5215 (1840-1848).

49 AESP, Fábrica de Ferro Ipanema, 15 de novembro de 1848. Ofício do diretor ao presidente da província de São Paulo. Ordem n ${ }^{\circ}$ CO 5215 (1840-1848). 
Sankofa. Revista de História da África e de Estudos da Diáspora Africana Ano VI, NºXII,

Dezembro/2013

simplistas referentes à mão-de-obra.

Por sua vez, a lista nominal dos africanos livres para 1849 declara as funções exercidas por eles, a data de chegada ao estabelecimento e suas naturalidades. As informações referentes às origens, na realidade, dizem respeito aos portos em que foram embarcados, e não aos locais exatos de nascimento daquelas pessoas. Ademais, a presença desses elementos nas fontes encontra-se esparsas, elas aparecem somente em algumas listagens, ou nos ofícios das fugas, juntamente com a discrição física dos evadidos.

Tabela 4: Relação nominal dos africanos livres maiores e menores, extraída do livro de matrícula dos mesmos, organizada em julho de 1849, declarando os que atualmente existem nesta Fábrica, os que tiveram desterros e os que faleceram. ${ }^{50}$.

Africanos livres maiores de 20 anos:

\begin{tabular}{|l|l|l|l|}
\hline Nome & $\begin{array}{l}\text { Naturalida } \\
\text { de }\end{array}$ & Aplicação & Observações \\
\hline 1-Francisco & Angola & $\begin{array}{l}\text { Trabalha nas } \\
\text { fundições de } \\
\text { forno alto e refino }\end{array}$ & $\begin{array}{l}\text { Veio para esta Fábrica } \\
\text { acompanhado da Portaria do } \\
\text { Exmo. Governo da Provincia, de } \\
\text { 28 de junho de 1835. }\end{array}$ \\
\hline 2-Bras & Benguela & Ferreiro & Idem \\
\hline 3-Lúcio & Cassange & Carreiro & Idem \\
\hline 4- Rogério & Congo & Carpinteiro & Idem \\
\hline 5- Balbino & Benguela & Ferreiro & Idem \\
\hline 6- Vicente & Congo & $\begin{array}{l}\text { No serviço do } \\
\text { mato }\end{array}$ & Idem \\
\hline 7-Gabriel & Benguela & Idem & Idem \\
\hline 8-Martinho & Congo & Ferreiro & Idem \\
\hline 9-Paulo & Angola & Idem & Idem \\
\hline 10-Basílio & Congo & Ferreiro & Idem \\
\hline 11-Inocêncio & Benguela & Ferreiro & Idem \\
\hline 12-Daniel & Idem & Moldador & Idem \\
\hline $\begin{array}{l}\text { 13- } \\
\text { Chrispiniano }\end{array}$ & Bié & Carreiro & Idem \\
\hline 14-Luciano & Benguela & Ferreiro & Idem \\
\hline
\end{tabular}

50 AESP, Fábrica de Ferro Ipanema, julho de 1849. Relação nominal dos africanos livres, extraída do livro de matrícula dos mesmos, declarando os que atualmente existem na Fábrica, os que tiveram desterros e os que faleceram. Ordem $n^{\circ}$ CO 5216 (1849-1870). A lista contém apenas informações dos africanos livres maiores de 20 anos. 
Sankofa. Revista de História da África e de Estudos da Diáspora Africana Ano VI, NºXI,

Dezembro/2013

\begin{tabular}{|c|c|c|c|}
\hline 15-Marcelino & Idem & Idem & Idem \\
\hline 16-Estevão & Angola & $\begin{array}{l}\text { No serviço do } \\
\text { mato }\end{array}$ & Idem, 06 de abril de 1836. \\
\hline 17-Bernardino & Rebolo & Servente & Idem \\
\hline 18-Diogo & Cassange & $\begin{array}{l}\text { No serviço do } \\
\text { mato }\end{array}$ & Idem \\
\hline 19-Antonio $1^{\circ}$ & Rebolo & Servente & Idem \\
\hline 20- Thaddéo & Tumbe & Idem & Idem \\
\hline 21-Juvencio & Rebolo & $\begin{array}{ll}\text { Trabalha } & \text { nas } \\
\text { fundições } & \text { dos } \\
\text { fornos altos } & \end{array}$ & $\begin{array}{l}\text { Veio para esta Fábrica } \\
\text { acompanhado da portaria do } \\
\text { Exmo. Governo da Província, de } \\
\text { 06 de abril de } 1836 .\end{array}$ \\
\hline $\begin{array}{l}22-\text { Anastácio } \\
1^{\circ}\end{array}$ & Goguin. & Servente & Idem em 06 de agosto de 1839. \\
\hline 23-Felis & Congo & $\begin{array}{l}\text { No serviço do } \\
\text { mato }\end{array}$ & Idem \\
\hline 24-Romão & Macúa & Idem & Idem \\
\hline $25-\operatorname{Braz} 2^{\circ}$ & Mogange & Idem & Idem \\
\hline 26-Raymundo & Idem & Carreiro & Idem \\
\hline 27-Augusto & Mucena & $\begin{array}{l}\text { No serviço do } \\
\text { mato }\end{array}$ & Idem \\
\hline 28-Bertholdo & Idem & Carreiro & Idem \\
\hline 29-Deziderio & Mogange & Soldador & Idem \\
\hline 30-Benedicto & Mucena & $\begin{array}{l}\text { No serviço do } \\
\text { mato }\end{array}$ & Idem \\
\hline 31-Aleixo & Macúa & Carreiro & Idem \\
\hline 32- Silvério & Mogange & Servente & Idem \\
\hline 33-Laurentino & Mogange & $\begin{array}{l}\text { No serviço do } \\
\text { mato }\end{array}$ & Idem \\
\hline 34- Jovito & Ilegível & Idem & Idem \\
\hline 35-Ollegario & Macúa & Idem & Idem \\
\hline 36-Belmiro & Mucena & Carreiro & Idem \\
\hline 37- Julião & Guintiqui & $\begin{array}{l}\text { Nas fundições dos } \\
\text { fornos altos }\end{array}$ & Idem \\
\hline 38-Rozendo & Congo & $\begin{array}{l}\text { No serviço do } \\
\text { mato }\end{array}$ & Idem \\
\hline 39- Cyrilo $1^{\circ}$ & Cabinda & Servente & Idem \\
\hline 40- Guilherme & \begin{tabular}{|l} 
Moçambiqu \\
$e$
\end{tabular} & $\begin{array}{l}\text { Nas fundições dos } \\
\text { fornos altos }\end{array}$ & Idem, 30 de janeiro de 1840. \\
\hline 41-André $1^{\circ}$ & Ozamba & Carreiro & Idem, 12 de março de 1840. \\
\hline $42-$ Braulio $1^{\circ}$ & Chificta & Tropeiro & Idem \\
\hline 43-Alippio & Mucena & Tropeiro & $\begin{array}{l}\text { Veio para esta Fábrica } \\
\text { acompanhado da portaria do } \\
\text { Exmo. Governo da Província, de } \\
12 \text { de março de } 1840 \text {. }\end{array}$ \\
\hline 44- $\quad$ Evaristo & Quilimane & Ilegível & Idem, 07 de maio de 1841. \\
\hline
\end{tabular}


Sankofa. Revista de História da África e de Estudos da Diáspora Africana Ano VI, NXII,

Dezembro/2013

\begin{tabular}{|c|c|c|c|}
\hline $1^{\circ}$ & & & \\
\hline 45- Pelaio & $\begin{array}{l}\text { Moçambiqu } \\
e\end{array}$ & $\begin{array}{l}\text { No serviço do } \\
\text { mato }\end{array}$ & Idem \\
\hline 46- Fulgencio & Quilimane & Tropeiro & Idem \\
\hline $\begin{array}{l}\text { 47- Marcolino } \\
2^{\circ}\end{array}$ & $\begin{array}{l}\text { Moçambiqu } \\
e\end{array}$ & Carreiro & Idem \\
\hline 48-Pedro & Quilimane & Moldador & Idem \\
\hline $\begin{array}{l}49- \\
\text { Hermogenio }\end{array}$ & Idem & $\begin{array}{l}\text { No serviço do } \\
\text { Mato }\end{array}$ & Idem \\
\hline $\begin{array}{l}50-\text { Eustáquio } \\
1^{\circ}\end{array}$ & Idem & Tropeiro & Idem \\
\hline $51-$ Lucio $2^{\circ}$ & Idem & $\begin{array}{l}\text { Nas fundições dos } \\
\text { fornos altos }\end{array}$ & Idem \\
\hline 52-Herculano & $\begin{array}{l}\text { Moçambiqu } \\
e\end{array}$ & Idem & Idem \\
\hline 53-Lucas & Quilimane & $\begin{array}{l}\text { No serviço do } \\
\text { mato }\end{array}$ & Idem \\
\hline 54-Gregorio & Idem & Idem & Idem \\
\hline 55-Caetano & $\begin{array}{l}\text { Moçambiqu } \\
e\end{array}$ & Nos pilões & $\begin{array}{l}\text { Idem, em janeiro de 1843. Não } \\
\text { consta a data da portaria. }\end{array}$ \\
\hline 56-Abrahão & Ilegível & $\begin{array}{l}\text { No serviço do } \\
\text { mato }\end{array}$ & Idem, de 09 de agosto de 1845. \\
\hline 57-Angelo & Noambo & Idem & Idem \\
\hline 58-Arnaldo & Utinanda & $\begin{array}{l}\text { Nas fundições dos } \\
\text { fornos altos }\end{array}$ & Idem \\
\hline 59-Bento & Barundo & Torneiro & Idem \\
\hline $60-$ Balbino $2^{\circ}$ & Mgarangue & $\begin{array}{l}\text { Nas fundições dos } \\
\text { fornos altos }\end{array}$ & Idem \\
\hline $61-\operatorname{Carlos} 1^{\circ}$ & Ilegível & $\begin{array}{l}\text { No serviço do } \\
\text { mato }\end{array}$ & Idem \\
\hline 62-Vencesláu & Congo & Servente & Idem \\
\hline $63-$ Antonio $2^{\circ}$ & Benguela & $\begin{array}{l}\text { No serviço do } \\
\text { mato }\end{array}$ & Idem \\
\hline 64-Antero & Cassambo & $\begin{array}{l}\text { No serviço do } \\
\text { mato }\end{array}$ & $\begin{array}{l}\text { Veio para esta Fábrica, } \\
\text { acompanhado da portaria do } \\
\text { Exmo. Governo da Província, de } \\
\text { 09 de agosto de } 1845 \text {. }\end{array}$ \\
\hline $\begin{array}{l}65- \\
\text { Appolinario }\end{array}$ & Ilegível & Idem & Idem \\
\hline 66-André $2^{\circ}$ & Ilegível & Idem & Idem \\
\hline 67-Agostinho & Benguela & Idem & Idem \\
\hline 68-Amadéo & Barundo & Idem & Idem \\
\hline 69-Andronico & Ilegível & $\begin{array}{l}\text { Nas fundições dos } \\
\text { fornos altos }\end{array}$ & Idem \\
\hline $70-\operatorname{Braz} 3^{\circ}$ & Cucera & Pedreiro & Idem \\
\hline 71- Bonifácio & Cacondo & No serviço do & Idem \\
\hline
\end{tabular}


Sankofa. Revista de História da África e de Estudos da Diáspora Africana Ano VI, NXII,

Dezembro/2013

\begin{tabular}{|c|c|c|c|}
\hline & & mato & \\
\hline 72-Bazílio $2^{\circ}$ & Ilegivel & Idem & Idem \\
\hline 73-Braulio $2^{\circ}$ & Ilegivel & Idem & Idem \\
\hline 74- Ilegivel & Ilegivel & Idem & Idem \\
\hline 75- Canuto & Cabia & Idem & Idem \\
\hline 76-Claudiano & Cacondo & Ferreiro & Idem \\
\hline 77-Cyrilo $2^{\circ}$ & Cabia & $\begin{array}{l}\text { No serviço do } \\
\text { mato }\end{array}$ & Idem \\
\hline $78-\operatorname{Carlos} 2^{\circ}$ & Ilegível & Moldador & Idem \\
\hline 79-Cantidio & Ilegivel & $\begin{array}{l}\text { No serviço do } \\
\text { mato }\end{array}$ & Idem \\
\hline 80-Cantidiano & Ilegivel & Idem & Idem \\
\hline 81-Chrispim & Calunda & Idem & Idem \\
\hline 82- Domingos & Ilegivel & Idem & Idem \\
\hline 83-Damião & Cacondo & Idem & Idem \\
\hline 84- Deolindo & Ilegivel & Idem & Idem \\
\hline 85- Damazio & Ilegivel & Carpinteiro & $\begin{array}{l}\text { Veio para esta Fábrica, } \\
\text { acompanhado da portaria do } \\
\text { Exmo. Governo da Província, de } \\
\text { 09 de agosto de } 1845 \text {. }\end{array}$ \\
\hline 86- Ilegível & Ilegivel & $\begin{array}{l}\text { No serviço do } \\
\text { mato }\end{array}$ & Idem \\
\hline 87-Diógenes & Cabinda & Idem & Idem \\
\hline 88-Esequiel & Idem & Idem & Idem \\
\hline 89- Ilegivel & Cacondo & Idem & Idem \\
\hline $\begin{array}{l}90-\text { Eustachio } \\
2^{\circ}\end{array}$ & Ilegivel & Moldador & Idem \\
\hline 91-Thomas & Ilegivel & Ilegivel & Idem \\
\hline 92-Libanio & Mogange & $\begin{array}{l}\text { No serviço do } \\
\text { mato }\end{array}$ & Idem \\
\hline 93-Antenôr & Barundo & Idem & Idem, de 19 de novembro de 1846. \\
\hline $\begin{array}{l}94-\text { Athanazio } \\
2^{\circ}\end{array}$ & Cassange & Idem & Idem \\
\hline 95-Alberto & Idem & Idem & Idem \\
\hline 96-Cosme & Cocauete & Idem & Idem \\
\hline 97-Casimiro & Calunda & Idem & Idem \\
\hline 98-Dario & Ilegivel & Servente & Idem \\
\hline $\begin{array}{ll}99- & \text { Evaristo } \\
2^{\circ} & \end{array}$ & Ilegivel & Idem & Idem \\
\hline 100- João $1^{\circ}$ & Macúa & Ilegivel & Idem, de 15 de setembro de 1847. \\
\hline 101-José $1^{\circ}$ & Idem & $\begin{array}{l}\text { No serviço do } \\
\text { mato }\end{array}$ & Idem \\
\hline $\begin{array}{l}\text { 102-Francisco } \\
2^{\circ}\end{array}$ & Moange & Idem & Nada consta \\
\hline
\end{tabular}


Sankofa. Revista de História da África e de Estudos da Diáspora Africana Ano VI, NºXII,

Dezembro/2013

\begin{tabular}{|c|c|c|c|}
\hline $\begin{array}{l}\text { 103- } \\
\text { Alexandre } 2^{\circ}\end{array}$ & Mina & Idem & $\begin{array}{l}\text { Veio para esta Fábrica, } \\
\text { acompanhado da portaria do } \\
\text { Exmo. Governo da Província, de } \\
18 \text { de janeiro de } 1849 \text {. }\end{array}$ \\
\hline 104- Amancio & Idem & Idem & Idem \\
\hline 105- Ambrozio & Idem & Idem & Idem \\
\hline 106-Adriano & Idem & Idem & Idem \\
\hline $\begin{array}{l}\text { 107- Anastácio } \\
2^{\circ}\end{array}$ & Mina & $\begin{array}{l}\text { No serviço do } \\
\text { mato }\end{array}$ & Idem \\
\hline 108-Clemente & Idem & Tropeiro & Idem \\
\hline 109-Carlos & Idem & Torneiro & Idem \\
\hline 110-Calisto & Idem & $\begin{array}{l}\text { No serviço do } \\
\text { mato }\end{array}$ & Idem \\
\hline 111-Claudio & Idem & Ilegivel & Idem \\
\hline 112- Cyro & Idem & Carreiro & Idem \\
\hline 113- Gregório & Idem & $\begin{array}{l}\text { No serviço do } \\
\text { mato }\end{array}$ & Idem \\
\hline 114-Eusebio & Idem & Idem & Idem \\
\hline $\begin{array}{l}\text { 115-Manoel d } \\
\text { 'Assumpção }\end{array}$ & Idem & Idem & Idem \\
\hline 116-Manoel & Idem & Idem & Idem \\
\hline 117- Simplicio & Idem & Idem & Idem \\
\hline
\end{tabular}

A análise da lista demonstra as funções dos africanos para o ano de 1849, desta forma contabilizamos as seguintes ocupações: no forno alto e refino (09), carreiros, (09), ferreiros (09), serventes (09), carpinteiros (02), torneiros (02), no serviço do mato (61), moldadores (04), tropeiros (05), soldador (01), nos pilões (01), pedreiro (01) e (04) com ocupações ilegíveis. O interessante é que para a referida data, a maioria dos tutelados realizavam atividades pouco especializadas, como o serviço do mato. Fato este que contraria a noção de que eles executavam grande parte da produção do ferro, pois os postos referentes à metalurgia (forno alto/refino, ferreiros, moldadores) continham apenas 22 indivíduos. Ou seja, 18,80\% do total. Apesar dos dados acima levantados fica claro que, mesmo sem as ocupações específicas, os africanos fizeram parte de toda a rotina de trabalho em Ipanema.

O maior grupo de tutelados (para o período) chegou ao empreendimento em 1845 e continha 37 pessoas, enquanto o menor entrou em 1847 e possuía 02 pessoas, não obstante, 
há também a presença de mais 02 indivíduos, os quais não constam informações. Deste modo, optamos por apresentar a tabela abaixo a fim de que haja melhor compreensão dos elementos expostos na fonte. Veja-se:

Tabela 5: Número de africanos e as respectivas datas de chegada na Fábrica de Ferro Ipanema (1835-1849) ${ }^{51}$

\begin{tabular}{|c|c|}
\hline Data & $\begin{array}{l}\text { Número de } \\
\text { africanos }\end{array}$ \\
\hline 1835 & 15 \\
\hline 1836 & 06 \\
\hline 1839 & 18 \\
\hline 1840 & 04 \\
\hline 1841 & 11 \\
\hline 1845 & 37 \\
\hline 1846 & 07 \\
\hline 1847 & 02 \\
\hline 1849 & 15 \\
\hline $\begin{array}{c}\text { Não } \\
\text { consta }\end{array}$ & 02 \\
\hline
\end{tabular}

Ainda sobre o referido documento, escolhemos também criar mais uma tabela a fim de exemplificar as origens dos trabalhadores. Na relação o maior número é composto de africanos minas (15 indivíduos), seguido pelos de Benguela (09), Quilimane ${ }^{52}(08)$, Congo (07), Mogange (06), Moçambique, Mucena e Macúa (05). Além dos grupos menores, os ilegíveis e não identificados. As denominações na relação nem sempre correspondiam fielmente às origens étnicas dos tutelados, pois muitas vezes as regiões citadas apontavam na realidade, os portos, ilhas ou locais de onde os africanos foram capturados. Nesse sentido, Reginaldo Prandi faz uma reflexão crucial:

A identidade da origem podia simplesmente estar referida ao porto de embarque. Embora cada porto concentrasse preferencialmente as presas das

51 Idem.

52 Atualmente corresponde a região de Moçambique. 
vizinhanças, a necessidade de manter portos de embarque afastados, para driblar a vigilância quando o tráfico começou a ficar ilegal, primeiro em certos segmentos da costa africana, mais tarde em todo o litoral, fez com que partidas de escravos alcançassem os portos depois de percorrer a pé, pelo interior, longos trajetos. Isso complicava a identificação do escravo, pois sua origem através do porto de embarque podia não mais corresponder a sua origem verdadeira. ${ }^{53}$

Ademais, as autoridades poderiam relatar inclusive a etnia a qual pertenciam, por exemplo, Macúa não era um lugar na África, mas sim uma tribo, grupo étnico. Logo, não existe homogeneidade nos nomes de procedência. Por conseguinte, os nãos identificados provavelmente deveriam corresponder a locais, grupos ou portos que foram extintos ao longo do tempo. Veja-se o número de africanos e locais de procedência:

Tabela 6: Relação do número de africanos e os locais de procedência ${ }^{54}$

\begin{tabular}{|l|l|l|}
\hline Procedência & $\begin{array}{l}\text { Número } \\
\text { africanos }\end{array}$ & $\begin{array}{l}\text { Porcentagem } \\
\text { \%o }\end{array}$ \\
\hline Angola & 03 & $2,5 \%$ \\
\hline Benguela & 09 & $7,6 \%$ \\
\hline Cassange & 04 & $3,4 \%$ \\
\hline Congo & 07 & $5,9 \%$ \\
\hline Bié & 01 & $0,85 \%$ \\
\hline Rebolo & 03 & $2,5 \%$ \\
\hline Macúa & 05 & $4,2 \%$ \\
\hline Mucena & 05 & $4,2 \%$ \\
\hline Cabinda & 03 & $2,5 \%$ \\
\hline Moçambique & 05 & $4,2 \%$ \\
\hline Quilimane & 08 & $6,8 \%$ \\
\hline Barundo & 03 & $2,5 \%$ \\
\hline Mguarangue & 01 & $0,85 \%$ \\
\hline Cassambo & 01 & $0,85 \%$ \\
\hline
\end{tabular}

53 PRANDI, Reginaldo. De africano a afro-brasileiro: etnia, identidade, religião. In: Revista USP, São Paulo, n.46, p. 52-65, junho/agosto 2000, p. 56.

54 Ibidem. 


\begin{tabular}{|l|l|l|}
\hline Cacondo & 04 & $3,4 \%$ \\
\hline Cabiá & 02 & $1,7 \%$ \\
\hline Calunda & 02 & $1,7 \%$ \\
\hline Cucera & 01 & $0,85 \%$ \\
\hline Cocauete & 01 & $0,85 \%$ \\
\hline Mina & 15 & $12,8 \%$ \\
\hline Mogange & 06 & $5,1 \%$ \\
\hline Moange & 01 & $0,85 \%$ \\
\hline $\begin{array}{l}\text { Não } \\
\text { Identificados }\end{array}$ & 07 & $5,9 \%$ \\
\hline Ilegível & 20 & $17 \%$ \\
\hline
\end{tabular}

Os estudos consolidados sobre o tráfico ${ }^{55}$ já demonstraram que os africanos vieram de três grandes regiões: Costa Oriental ${ }^{56}$, Costa Ocidental da África (Costa da Mina ${ }^{57}$ e da África Centro-Ocidental ${ }^{58}$. Todavia, as fontes podem apresentar registros genéricos como "Angola", "Luanda" e "Cassange", lugares conhecidos como mercados de escravos. Um trabalho interessante é o de Mariza Soares ${ }^{59}$, o qual buscou compreender as variações da identidade "Mina", pois apresentava aspectos diferentes no Sudeste e na Bahia. Nesta, eles possuíam identidades separadas por ser proporcionalmente mais numerosos. Já no Sudeste, a autora concluiu que, os "Mina" foram identificados como todos os africanos da Costa

55 FLORENTINO, Manolo. Em Costas Negras: uma história do tráfico de escravos entre a África e o Rio de Janeiro. São Paulo: Companhia das Letras, 1997. KARASCH, Mary. A vida dos escravos no Rio de Janeiro, 1808-1850. São Paulo: Companhia das Letras, 2000. MAMIGONIAN, Beatriz G. Do que "o preto mina” é capaz: etnia e resistência entre africanos livres. In: Afro-Asia, 24 (2000), pág.71-95. OLIVEIRA, Maria Inês Côrtes de. "Viver e Morrer no Meio dos Seus: Nações e Comunidades Africanas na Bahia do Século XIX”. In: Revista USP, n² 28, pp. 174-93, 1996. OLIVEIRA, Maria Inês Côrtes de. “Quem Eram os 'Negros da Guiné'? A Origem dos Africanos da Bahia”. In: Afro-Ásia, no 19-20, 1997 (1999). SLENES, Robert W. “Malungu, ngomavem!”: África coberta e descoberta do Brasil. In: Revista da USP n¹2. (1991/1992). pp. 48-67. SLENES, Robert W. Na Senzala, uma Flor: Esperanças e Recordações na Formação da Família Escrava - Brasil Sudeste, século XIX. Rio de Janeiro: Nova Fronteira, 1999. SOARES, Mariza de Carvalho. Os Mina em Minas: Tráfico Atlântico, Redes de Comércio e Etnicidade. Anais do XX Simpósio Nacional da ANPUH - História: São Paulo: Humanitas/Anpuh, 1999, p. 689-685. SOARES, Mariza de Carvalho. Mina, Angola e Guiné: Nomes d'África no Rio de Janeiro Setecentista. Tempo3 (1998). pp. 73-93. VERGER, Pierre. Fluxo e refluxo do tráfico de escravos entre o Golfo do Benin e a Bahia de todos os santos: dos séculos XVII a XIX. Brasília: Ministério da Cultura, 1987.

56 A Costa Oriental do continente africano é banhada pelo Oceano Índico e compreende as regiões de Moçambique, Sudão, Egito, Etiópia, etc.

57 Também é conhecida como costa dos escravos, ilustrada pelas culturas dos povos ioruba ou nagô. Atualmente compreende os territórios da Nigéria, Benim, Togo, Gana e Costa do Marfim.

58 Formada pelas regiões de Congo, Angola, Cabo Verde, Camarões, São Tomé e Príncipe, etc.

59 SOARES, Mariza de Carvalho. Devotos da cor: identidade étnica, religiosidade e escravidão no Rio de Janeiro, século XVIII. Rio de Janeiro: Civilização Brasileira, 2000. 
Ocidental. Ademais, segundo Mary C. Karasch ${ }^{60}$, embora a etnia incluísse também os iorubas, aussás, tapas e outros grupos, eles compuseram menos de $7 \%$ da população de escravos e africanos no Rio de Janeiro oitocentista. Tendo em vista os aspectos observados, os tutelados enviados à fábrica de ferro, entre o período 1835 a 1849, eram em grande parte provenientes das regiões da África Central e Centro- Ocidental, prevalecendo o grupo mina, extremamente importantes no processo da diáspora.

\section{Conclusão}

O texto apresentado foi apenas um recorte da atual pesquisa de Mestrado, a qual ainda há questionamentos, análises e considerações a realizar. Por sua vez, a historiografia ainda carece de estudos que deem ênfase ao cotidiano desses trabalhadores, suas origens étnicas, seu modo de viver, pensar e agir durante sua atuação nos empreendimentos públicos ou particulares. Assim, a importância do presente trabalho encontra-se no aprofundamento da experiência desses africanos (livre de direito, escravos de fato) na fábrica, ou seja, costumes, resistências, conflitos e solidariedades. Por conseguinte, tal estudo pode vir a recuperar um fragmento do mundo do trabalho compulsório, no século XIX, visto que a consciência dos tutelados da sua condição oficial de não escravo era usada como premissa para suas reivindicações; encarando-os como sujeitos históricos e atuantes à resistência do sistema escravista, podendo assim, somar-se aos estudos referentes à escravidão e liberdade dos povos africanos e afro-brasileiros.

\section{Referências Bibliográficas}

ALBULQUERQUE, Wlamyra R. de. Uma história do negro no Brasil. Salvador: Centro de Estudos Afro-Orientais; Brasília: Fundação Cultural Palmares, 2006.

ALGRANTI, Leila Mezan. O feitor ausente: estudo sobre a escravidão urbana no Rio de Janeiro 1808-1821. Petrópolis-RJ: Ed. Vozes, 1988.

ALMEIDA, Aluísio. História de Sorocaba, 1822-1889, vol.2. Gráfica Guarani: Sorocaba, 1951.

60 KARASCH, Mary. A vida dos escravos no Rio de Janeiro, 1808-1850. São Paulo: Companhia das Letras, 2000, p. 15. 
ARAÚJO NETO, Adalberto C. Sorocaba operária: ensaio sobre o início do movimento operário em Sorocaba: 1870-1920. Ed. Crearte: Sorocaba, 2005.

ARAÚJO, Carlos Eduardo Moreira. Arquitetando a liberdade: os africanos livres e as obras públicas no Rio de Janeiro imperial. In: História Unisinos, 14(3):329-333, Setembro/Dezembro 2010.

, Carlos Eduardo Moreira. Cárceres Imperiais: A Casa de Correção no Rio de Janeiro. Seus detentos e o sistema prisional no Império (1830-1861). Tese de Doutorado. Campinas-SP: UNICAMP, 2009.

AZEVEDO, Elciene. O direito dos escravos: lutas jurídicas e abolicionismo na Província de São Paulo. Ed. UNICAMP: Campinas, São Paulo, 2010.

BERTIN, Enidelce. Os meia cara. Os africanos livres em São Paulo no século XIX. Tese de Doutorado. Departamento de História. Universidade de São Paulo, 2006.

BUARQUE DE HOLANDA, Sérgio. História geral da civilização brasileira. tomo II: O Brasil Monárquico, $2^{\circ}$ volume: Dispersão e Unidade. Ed. DIFEL: São Paulo, 1964.

CHALHOUB, Sidney. Visões da Liberdade: uma história das últimas décadas da escravidão na corte. Ed. Companhia das Letras: São Paulo, 1998.

, Sidney. Sujeitos no imaginário acadêmico: escravos e trabalhadores na historiografia brasileira desde os anos de 1980. In: Cadernos AEL, vol.14, nº 16, 2009.

Sidney. Cidade febril: cortiços e epidemias na Corte imperial. São Paulo: Companhia das Letras, 1996.

CONRAD, Robert. Tumbeiros, o tráfico de escravos para o Brasil. Ed. Brasiliense: São Paulo, 1985.

COSTA, Emília Viotti. Da Senzala à Colônia. Ed. DIFEL: São Paulo, 1966.

DANIELI, Mario Neto. Escravidão e Indústria: Um estudo sobre a Fábrica de Ferro São João do Ipanema-Sorocaba (SP)-1765-1895. Doutorado em História, Universidade Estadual de Campinas, Instituto de Economia, 2006.

DAVIS, David Brion. O problema da escravidão na cultura ocidental. Rio de Janeiro: Civilização Brasileira, 2001,

DRESCHER, Seymour. Abolição: uma história da escravidão e do anti-escravismo. São Paulo: Ed. da UNESP, 2011.

FLORENCE, Afonso Bandeira. Entre o cativeiro e a emancipação: A liberdade dos africanos livres no Brasil (1818-1864). Dissertação de Mestrado. Salvador: Universidade Federal da Bahia, 2002.

KARASCH, Mary, C. A vida dos escravos no Rio de Janeiro, 1808-1850. Ed. Companhia das Letras: São Paulo, 2000.

MAMIGONIAN, Beatriz Galotti. To be a liberated African in Brazil: labour and citzenship in the nineteenth century. PhD, History. Waterloo: University of Waterloo, 2002. 
, Beatriz Galotti. O direito de ser africano livre. Os escravos e as interpretações de 1831. In: (org) LARA, Silvia Hunold e MENDONÇA, Maria Nunes. Direitos e Justiças no Brasil: ensaios de História Social. Ed. Unicamp: Campinas, 2006.

, Beatriz Galotti. Do que "o preto mina" é capaz: etnia e resistência entre africanos livres. In: Afro-Ásia, 24 (2000), pág.71-95.

MATTOS, Ilmar Rohloff. O tempo Saquarema. Rio de Janeiro: ACCESS, 1994.

MOREIRA, Alinnie Silvestre. Os africanos livres e as relações de trabalho na Fábrica de Pólvora da Estrela, Serrada Estrela- RJ (1831-1870). Dissertação de Mestrado em História. Campinas: UNICAMP, 2005.

PEREIRA, Júlio César Medeiros da Silva. À flor da terra: O cemitério dos pretos novos no Rio de Janeiro. Rio de Janeiro: Garamond : IPHAN, 2007

PEREIRA, Osny D. Ferro e Independência, Um desafio à dignidade nacional. Ed. Civilização Brasileira, São Paulo, 1967.

RIBEIRO, Mariana Alice.P.S. Na senzala, o escravo operário: um estudo sobre a escravidão, fugas e conflitos na Fábrica de Ferro São João do Ipanema- Sorocaba-SP (1835-1838). Relatório final de pesquisa apresentado à Fundação de Amparo à Pesquisa do Estado de São Paulo, 2010.

RODRIGUES, Jaime. O infame comércio: propostas e experiências no final do tráfico de africanos para o Brasil (1800-1850). Campinas: Ed. UNICAMP- CECULT, 2000.

, Jaime. Ferro, Trabalho e Conflito: os africanos livres na Fábrica de Ipanema In: História Social UNICAMP, Campinas, nº 4/5, 1997.

Jaime. O fim do tráfico transatlântico de escravos para o Brasil: paradigmas em questão. In: GRIMBERG, Keila e SALLES, Ricardo. O Brasil Imperial (1831 a 1870). Ed. Civilização Brasileira: Rio de Janeiro, 2009.

SANTOS, Nilton Pereira de. A Fábrica de Ferro São João de Ipanema: economia e política nas últimas décadas do Segundo Reinado (1860-1889). Dissertação de Mestrado em História. São Paulo: USP-FFLCH, 2009.

SILVA, Juliana Ribeiro da. Homens de ferro: Os ferreiros na África Central no século XIX. São Paulo: Alameda, 2011.

SLENES, Robert W. Na senzala, uma flor: esperanças e recordações na formação da família escrava, Brasil, Sudeste, século XIX. Nova Fronteira: Rio de Janeiro, 1999.

SOARES, Mariza de Carvalho. Devotos da cor: identidade étnica, religiosidade e escravidão no Rio de Janeiro, século XVIII. Rio de Janeiro: Civilização Brasileira, 2000.

, Mariza de Carvalho. Os Mina em Minas: Tráfico Atlântico, Redes de Comércio e Etnicidade. Anais do XX Simpósio Nacional da ANPUH - História: São Paulo: Humanitas/Anpuh, 1999, p. 689-685.

SOUZA, Jorge Prata de. Africano livre ficando livre: Trabalho, Cotidiano e Luta. Tese de Doutorado em História Social. São Paulo: Universidade de São Paulo, 1999. 
Sankofa. Revista de História da África e de Estudos da Diáspora Africana Ano VI, NºXI,

Dezembro/2013

THOMPSON, Edward P. A formação da classe operária inglesa, vol. 1. Ed. Paz e Terra: Rio de Janeiro, 1987.

WISSENBACH, Maria Cristina Cortez. Sonhos Africanos, vivências ladinas: escravos e forros em São Paulo (1850-1888). Editora Hucitec: São Paulo, 1998. 